Supplement of

\title{
Dithiothreitol activity by particulate oxidizers of SOA produced from photooxidation of hydrocarbons under varied $\mathrm{NO}_{x}$ levels
}

Huanhuan Jiang et al.

Correspondence to: Myoseon Jang (mjang@ufl.edu)

The copyright of individual parts of the supplement might differ from the CC BY 3.0 License. 


\section{Section S1. Outdoor chamber experiments.}

A non-reactive compound, $\mathrm{CCl}_{4}(500-1000 \mathrm{ppb})$, was injected into the chamber as a dilution tracer. Gas phase concentrations of hydrocarbons $(\mathrm{HCs})$ and $\mathrm{CCl}_{4}$ were measured by a gas chromatography-flame ionization detector (GC-FID, HP-5890). The concentration of $\mathrm{NO}_{x}$ was 5 monitored by a chemiluminescence analyzer (Teledyne, Model T201). The concentration of $\mathrm{O}_{3}$ was monitored by a photometric ozone analyzer (Teledyne, Model 400E). The relative humidity and temperature were monitored by a hygrometer (CS215-L, Campbell Scientific). The typical time profiles of SOA mass concentration, $\mathrm{HCs}$ (i.e. toluene and $\mathrm{TMB}$ ), $\mathrm{NO}_{x}, \mathrm{NO}$ and $\mathrm{O}_{3}$ mixing ratios through the experiments were shown in Fig. S1.

(a) Toluene $\left(\mathrm{HC} / \mathrm{NO}_{x}=9 \mathrm{ppbC} / \mathrm{ppb}\right)$

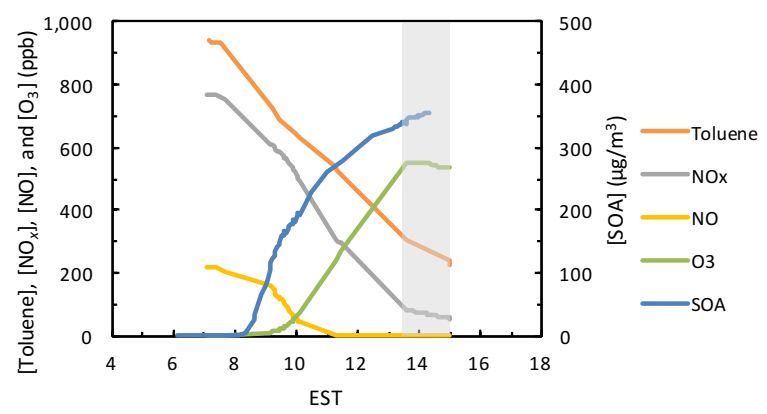

(b) Toluene $\left(\mathrm{HC} / \mathrm{NO}_{x}=22 \mathrm{ppbC} / \mathrm{ppb}\right)$

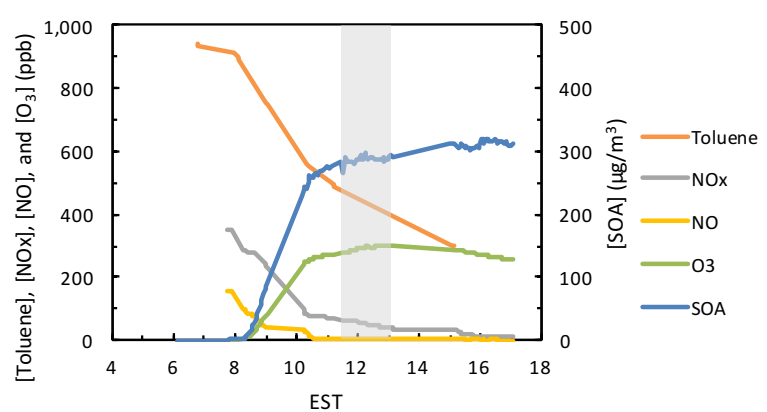

(c) $\mathrm{TMB}\left(\mathrm{HC} / \mathrm{NO}_{x}=6 \mathrm{ppbC} / \mathrm{ppb}\right)$

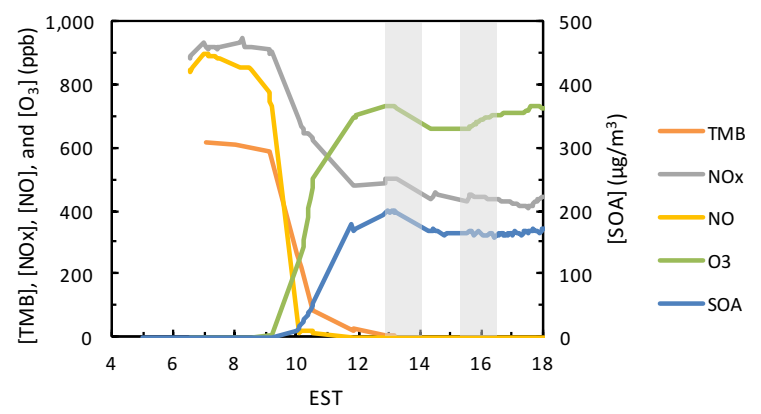

(d) TMB ( $\left.\mathrm{HC} / \mathrm{NO}_{x}=19 \mathrm{ppbC} / \mathrm{ppb}\right)$

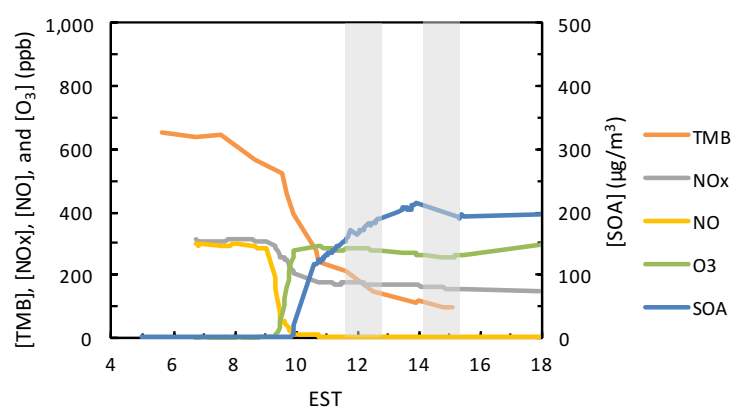

Figure $\mathrm{S} 1$. The time profiles of $\mathrm{SOA}$ mass concentration, $\mathrm{HCs}, \mathrm{NO}_{x}, \mathrm{NO}$ and $\mathrm{O}_{3}$ mixing ratios through the experiments: (a) toluene $\left(\mathrm{HC} / \mathrm{NO}_{x}=9 \mathrm{ppbC} / \mathrm{ppb}\right)$; (b) toluene $\left(\mathrm{HC} / \mathrm{NO}_{x}=22\right.$ $\mathrm{ppbC} / \mathrm{ppb})$; (c) TMB (HC/NO$=6 \mathrm{ppbC} / \mathrm{ppb})$; (d) TMB (HC/NO$=19 \mathrm{ppbC} / \mathrm{ppb})$. EST, Eastern Standard Time. The shaded areas indicate the time periods of aerosol sampling. 


\section{Section S2. Chemicals and solution preparation for chemical assays.}

Toluene (99.5\%), 1,3,5-trimethylbenzene (99\%), and hydrogen peroxide (50 wt.\% aqueous solution) were from Acros Organics (NJ, USA). Isoprene (99 \%), $\alpha$-pinene (98\%), $\mathrm{CCl}_{4}(99.9$ $\%$ ), potassium phosphate buffer $(0.1 \mathrm{M}), 9,10$-phenanthraquinone (99 \%), 1,4-naphthoquinone

5 (97\%), mesityl oxide (90\%), 2,4-hexadienal (>95\%), sulfanilic acid (99\%), n-(1-naphthyl) ethylenediamine dihydrochloride ( $\geq 98 \%$ ), potassium hydroxide ( $\geq 85 \%$ ), sodium nitrite ( $\geq 97$ $\%$ ), tert-butyl hydroperoxides (5.0-6.0 $\mathrm{M}$ in decane), peracetic acid (32 wt.\%), tert-butyl peroxide (98\%), dimethyl sulfoxide (99.9\%) and 4-nitrophenyl boronic acid ( $\geq 95 \%)$ were from Sigma-Aldrich (St. Louis, MO, USA). Dithiothreitol (99 \%), Tris base (99.8-100.1 \%), 5,5'-

10 dithiobis-(2-nitrobenzoic acid) (99\%), trichloroacetic acid (99\%), and deionized (DI) water (ACS, ASTM Type I) were obtained from Thermo Fisher Scientific (Pittsburgh, PA, USA). Acrolein (97\%, stabilized by hydroquinone) was from Alfa Aesar (Ward Hill, MA, USA).

The preparation details of 9,10-phenanthraquinone (PQN), 1,4-naphthoquinone (NQN), tertbutyl peroxides, and tert-butyl hydroperoxides were shown below:

15 PQN stock solution: $5 \mathrm{mM}$ PQN standard stock solution was made by dissolving $20.821 \mathrm{mg}$ of PQN in $20 \mathrm{~mL}$ DMSO. The stock solution was kept at $4{ }^{\circ} \mathrm{C}$ when not in use. Before chemical analysis, the PQN stock solution was diluted using DI water.

NQN standard: $5 \mathrm{mM}$ NQN standard stock solution was made by dissolving $31.630 \mathrm{mg}$ of NQN in $20 \mathrm{~mL}$ DMSO. The stock solution was kept at $4{ }^{\circ} \mathrm{C}$ when not in use. Before chemical

20 analysis, the NQN stock solution was diluted using DI water.

Tert-butyl peroxide: $26 \mathrm{mM}$ tert-butyl peroxide solution was prepared by adding $0.1 \mathrm{~mL}$ tertbutyl peroxide (98\%) into $20 \mathrm{~mL}$ DI water. The tert-butyl peroxides stock solution was further diluted to get a $100 \mu \mathrm{M}$ solution using DI water.

Tert-butyl hydroperoxides: $22 \mathrm{mM}$ tert-butyl hydroperoxide solution was prepared by adding

$250.08 \mathrm{~mL}$ tert-butyl hydroperoxide (5.0-6.0 $\mathrm{M}$ in decane) into $19.92 \mathrm{~mL}$ methanol. The tert-butyl hydroperoxides stock solution was further diluted to get a $96 \mu \mathrm{M}$ solution using methanol. 


\section{Section S3. Reaction schemes for chemical assays.}

DTT assay. DTT assay was employed to quantify the oxidative potential of SOA (Cho et al., 2005; Jiang et al., 2016). DTT was oxidized when mixed with SOA. The remaining DTT can be quantified using 5,5'-dithiobis-(2-nitrobenzoic acid), which reacts with DTT forming 2-nitro-5-

5 thiobenzoic acid, as shown in Scheme S1.

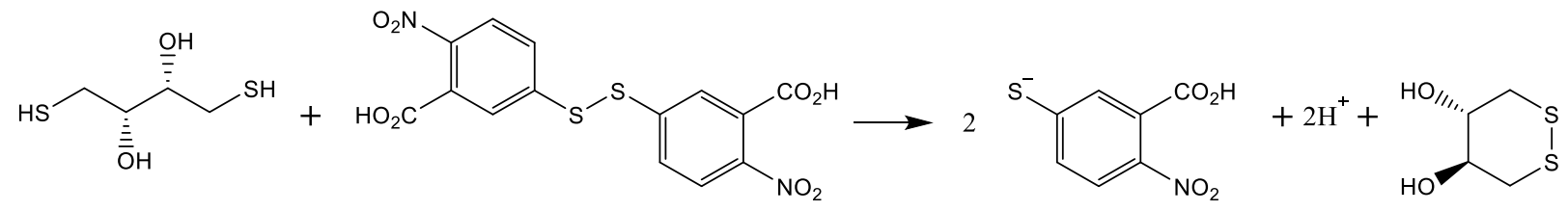

Dithiothreitol (DTT)

5,5'-dithiobis-(2-nitrobenzoic acid)

2-nitro-5-thiolbenzoic acid

Scheme S1. The DTT quantification using 5,5'-dithiobis-(2-nitrobenzoic acid).

NPBA assay. Organic hydroperoxides react with 4-nitrophenylboronic acid (NPBA) producing 4-nitrophenol (Scheme S2) which has a large absorption coefficient at $406 \mathrm{~nm}$.
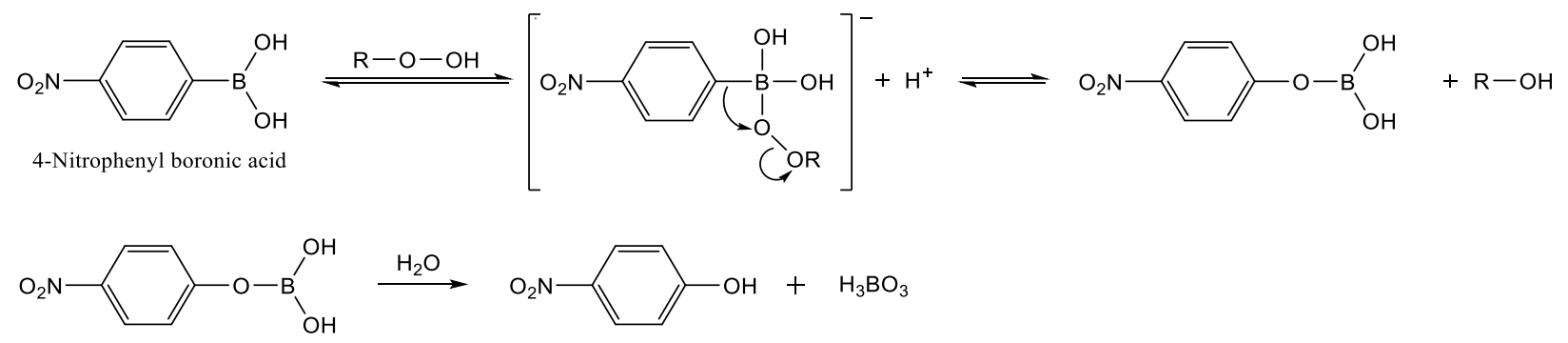

Scheme S2. The reaction between NPBA and organic hydroperoxides (Kuivila, 1954; Kuivila and Armour, 1957).

15 Griess assay. PAN is hydrolysed by $\mathrm{KOH}$ and forms nitrites. A nitrite reacts with the Griess reagent (sulfanilic acid and n-(1-naphthyl) ethylenediamine dihydrocloride) to form an azo dye, as shown in Scheme S3.
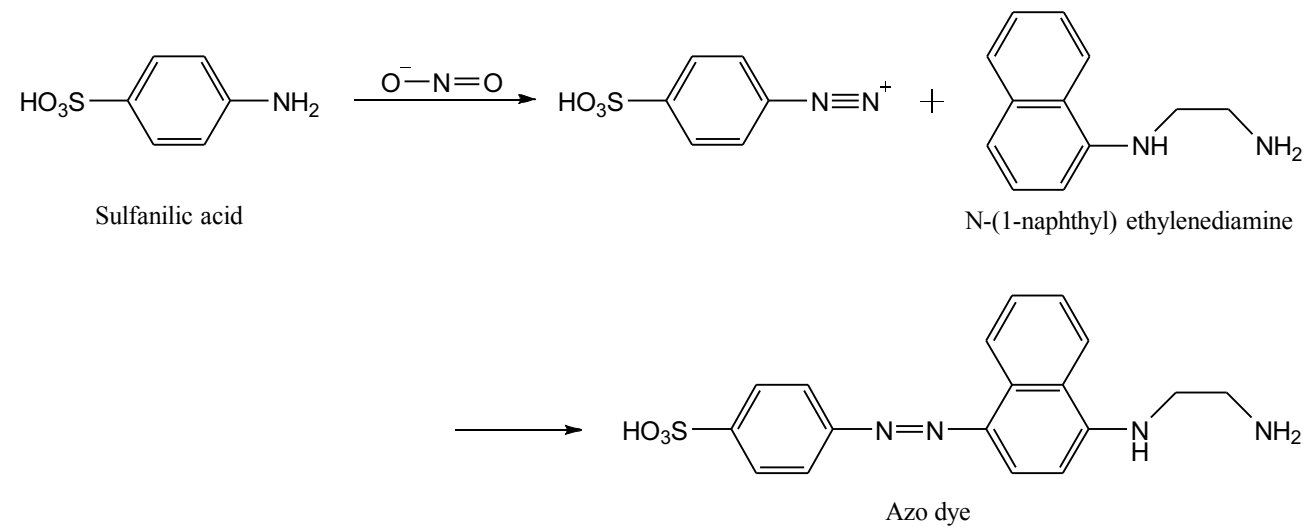

Scheme S3. The reaction between Griess reagent (sulfanilic acid and n-(1-naphthyl ethylenediamine) and nitrites (Giustarini et al., 2008). 
DTT enhancement assay. By forming H-bonds with hydroquinones, 2,4-dimethylimidazole facilitated the electrons transfer from hydroquinones to molecular oxygen, accelerating the redox cycling of quinones and enhancing the oxidation of DTT, as shown in Scheme S4 (Dou et al., 2015).

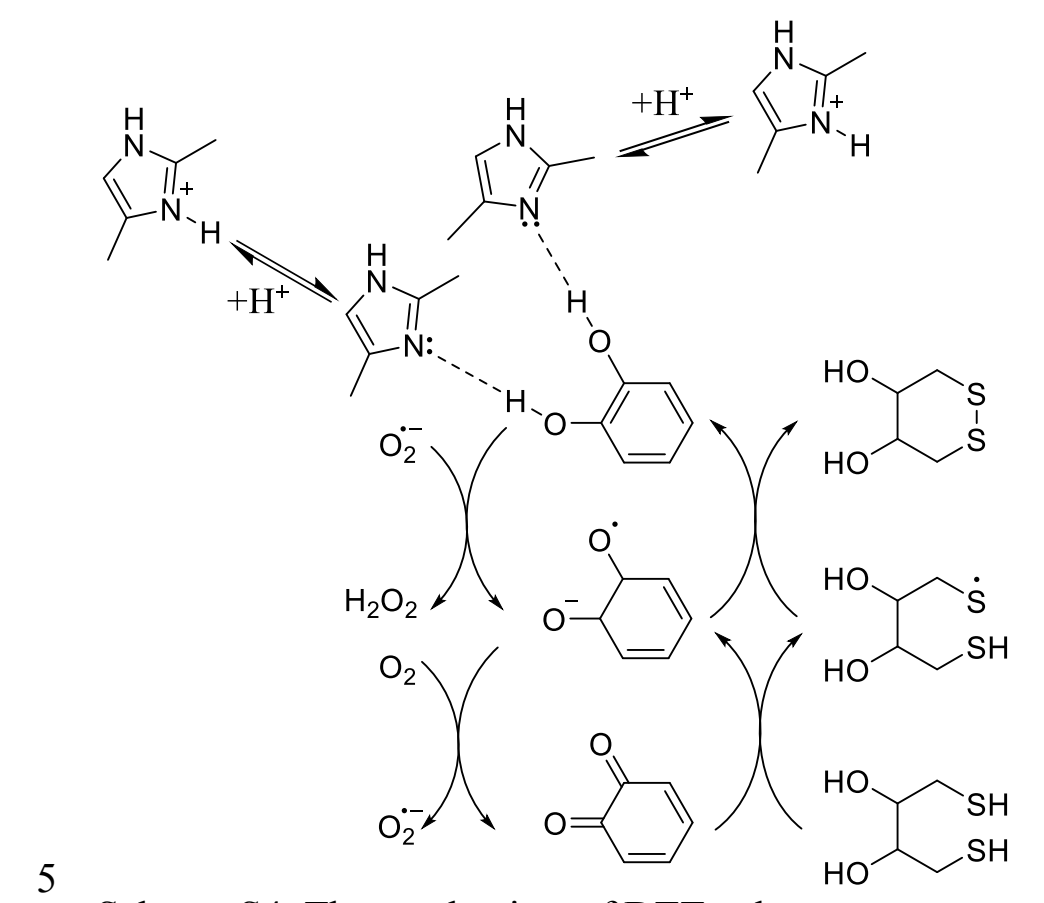

Scheme S4. The mechanism of DTT enhancement assay (Dou et al., 2015). 


\section{Section S4. QC/QA for the chemical assays}

\section{S4.1. DTT assay.}

Limit of detection (LOD). LOD is defined as three times the standard deviation $(\sigma)$ of blank

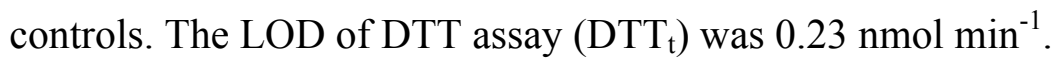

5 Blank control. To estimate the effect of radicals produced by sonication on DTT assay, the DTT loss rate in blank control during sonication was compared to that during shaking (Edison Environmental Incubator Shaker G24, low speed, $37^{\circ} \mathrm{C}$ ). As shown in Fig. S2, the DTT loss rate in blank control was $0.162 \mathrm{nmol} \mathrm{min}{ }^{-1}$ during sonication and $0.153 \mathrm{nmol} \mathrm{min}{ }^{-1}$ during shaking. Tested using the statistical method based on the Student t-test (Andrade and Estévez-Pérez,

10 2014), the slope of DTT loss vs. time with the sonicator was not significantly different from the one with the shaker (significance level $\alpha=0.05$ ); therefore, in this study, the influence of free radicals generated by sonication on DTT measurement was insignificant.

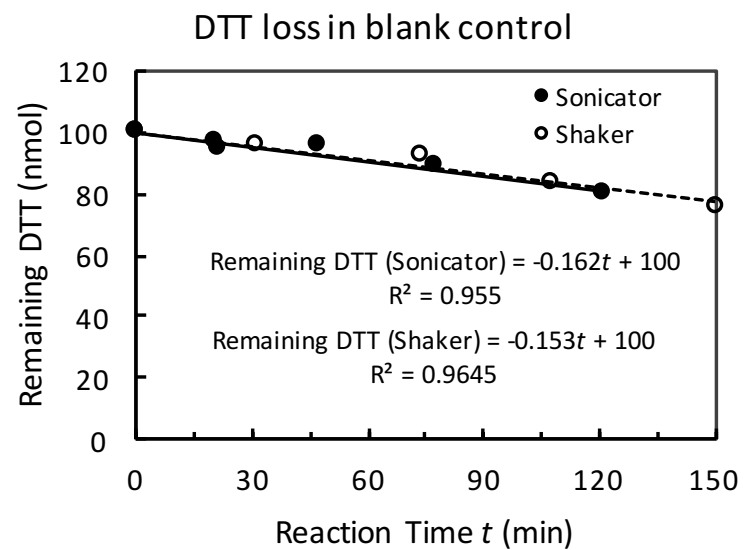

Figure S2. DTT loss in blank control (deionized water) during sonication or shaking $\left(37^{\circ} \mathrm{C}\right)$.

15 Positive controls. The DTT consumption of positive controls (PQN and NQN) was measured. As shown in Fig. S3, the DTT consumption of quiones increased linearly with reactin time due to the catalytic reactions between quinones and DTT. 


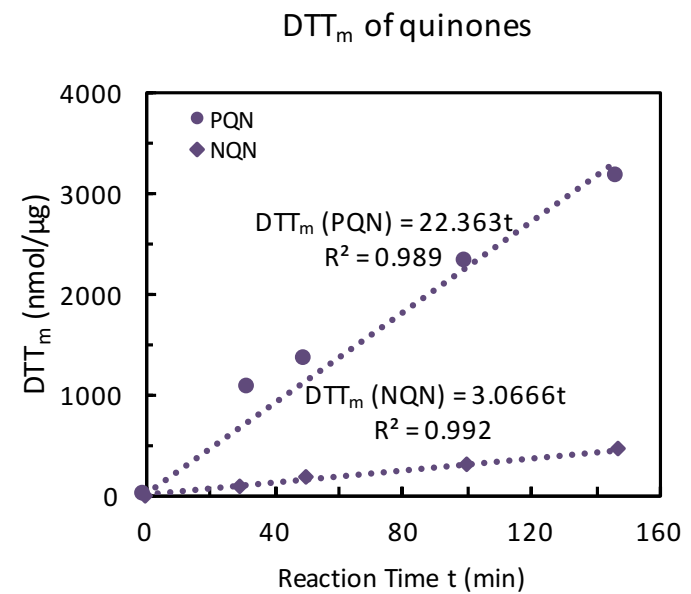

Figure S3. DTT $\mathrm{m}$ of quinones (PQN: 9,10-phenathraquinone, NQN: 1,4-naphthoquinone).

The stability of peroxides. To investigate the impact of the stability of organic compounds on

5 DTT actitivities, the DTT consumptions $(\Delta \mathrm{DTT}$ at reaction time $=100 \mathrm{~min})$ by $400 \mu \mathrm{L} \mathrm{H}_{2} \mathrm{O}_{2}(100$ $\mu \mathrm{M})$ and $300 \mu \mathrm{L}$ peracetic acid $\left(\mathrm{CH}_{3} \mathrm{C}(\mathrm{O}) \mathrm{OOH} ; 100 \mu \mathrm{M}\right)$ were measured as a function of storage time. As shown in Fig. S4, $\Delta$ DTT of $\mathrm{H}_{2} \mathrm{O}_{2}$ and $\mathrm{CH}_{3} \mathrm{C}(\mathrm{O}) \mathrm{OOH}$ stored at room temperature (RM) decreased upto $80 \%$ and $36 \%$ after an 8-day storage, respectivley. $\Delta \mathrm{DTT}$ of $\mathrm{CH}_{3} \mathrm{C}(\mathrm{O}) \mathrm{OOH}$ stored at $4{ }^{\circ} \mathrm{C}$ also decreased $22 \%$ after a 6 -day storage.

Relative DTT response to fresh sample

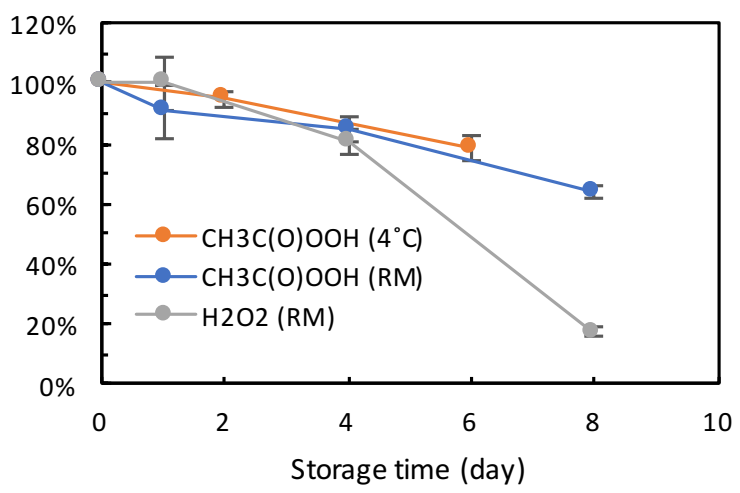

10

Figure S4. The DTT responses of $\mathrm{H}_{2} \mathrm{O}_{2}$ and peracetic acid stored at room temperature (RM) or 4 ${ }^{\circ} \mathrm{C}$. The errors was estimated using the standard deviation of three replicates.

The additivity of DTT activity by chemical species. To investigate the additivity of DTT response from different types of chemical species, $\triangle \mathrm{DTT}$ of the blend of several compounds was 15 compared with the sum of $\triangle \mathrm{DTT}$ originating from individual compounds. Fig. S5 proves that DTT consumption is additive by showing that $\triangle \mathrm{DTT}$ of the mixture of four model compounds 
(i.e., acrolein, $\mathrm{PQN}, \mathrm{H}_{2} \mathrm{O}_{2}$, and tert-butyl hydroperoxides) was consistent with the sum of individuals.

$\triangle D T T$ of a mixture of model compounds

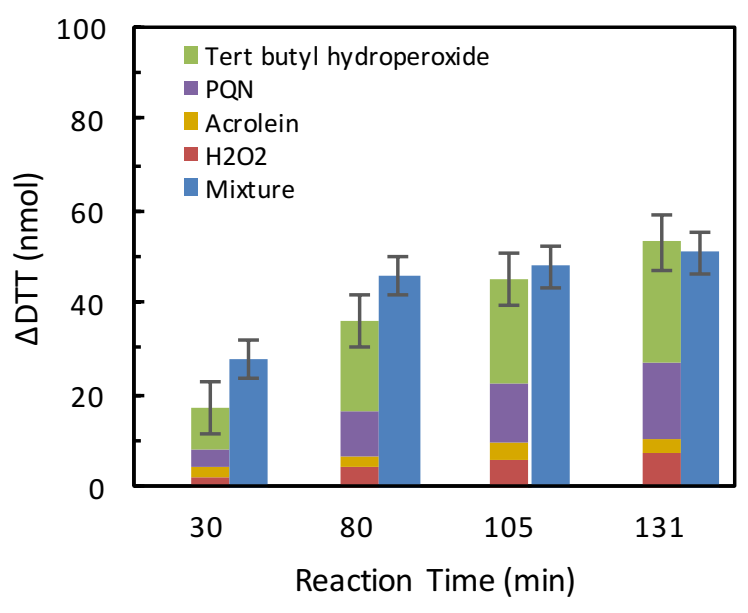

Figure S5. $\triangle \mathrm{DTT}$ of individual model compounds and the compounds mixture (54 nmol acrolein, $515 \mathrm{nmol} \mathrm{H}_{2} \mathrm{O}_{2}, 280 \mathrm{nmol}$ tert-butyl hydroperoxides, $\left.0.025 \mathrm{nmol} \mathrm{PQN}\right)$. The error bar associated with $\triangle \mathrm{DTT}$ of a stacked column was estimated by the sum of the error bars from individuals. 


\section{Section S4.2. NPBA assay.}

Limit of detection. The LOD of NPBA assay was $0.47 \mu \mathrm{M}$.

Calibration. The NPBA method was calibrated using aqueous 4-nitrophenol solutions ranging from 1-40 $\mu \mathrm{M}$, as shown in Fig. S6.

\section{NPBA calibration}

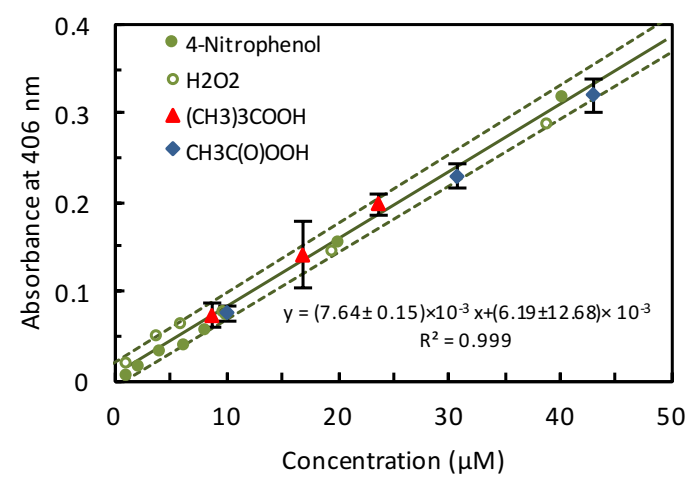

Figure S6. The calibration curve of NPBA assay was obtained at the $90 \%$ confidence level. The calibration curve was applied to test the feasibility of using NPBA assay to quantify the concentration of $\mathrm{H}_{2} \mathrm{O}_{2}$, tert-butyl hydroperoxides $\left(\left(\mathrm{CH}_{3}\right)_{3} \mathrm{COOH}\right)$, and peracetic acid $\left(\mathrm{CH}_{3} \mathrm{C}(\mathrm{O}) \mathrm{OOH}\right)$.

10 The time dependence of NPBA assay. To investigate the reaction time needed to quantify the organic hydroperoxides concentration using NPBA assay, the toluene SOA and isoprene SOA samples were incubated with NPBA at $85{ }^{\circ} \mathrm{C}$ for different reaction time. As shown in Fig. S7, the reaction of organic hydroperoxides with NPBA completed within $7 \mathrm{~h}$ for toluene SOA and $2 \mathrm{~h}$ for isoprene SOA.
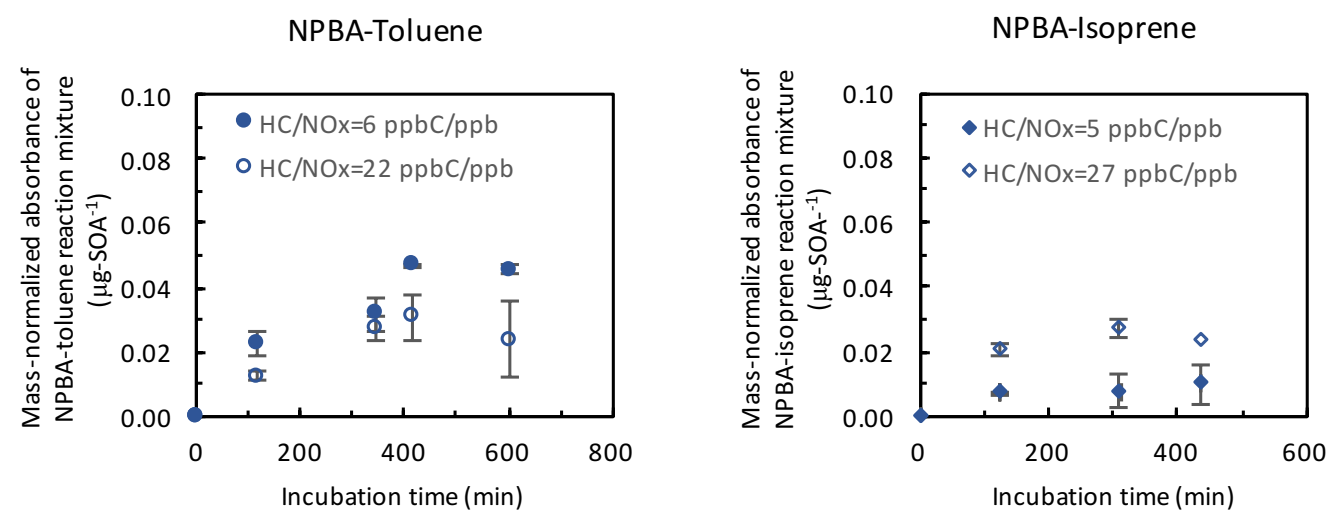

15

Figure S7. Time profile of the absorbance (normalized by SOA mass) of NPBA-SOA reaction mixture at $85{ }^{\circ} \mathrm{C}$. The error bar of each data point represents the standard deviation of three replicates. 
The influence of multi-alcohols and 4-nitrophenol on NPBA assay. It has been reported that boronic acid can react with multi-alcohols to form colorful products (Kim et al., 2007). SOA products are usually multifunctional and contain multi-alcohols. To examine the possible 5 interference by NPBA-alcohol adducts, the glycerol aqueous solution was applied to the NPBA method. However, no measurable absorption appeared in the UV spectrum. 4-Nitrophenol, a NPBA assay product, can be found in toluene SOA and potentially influences on NPBA data. However, the light absorption of the SOA sample collected using PILS was negligible at $406 \mathrm{~nm}$, suggesting that NPBA data is not influenced by the light absorbing materials in SOA products.

10 The stability of peroxides. To investigate the impact of the stability of peroxides on NPBA assay, the NPBA repsonses for $400 \mu \mathrm{L} \mathrm{H}_{2} \mathrm{O}_{2}(100 \mu \mathrm{M})$ and $300 \mu \mathrm{L}$ peracetic acid $(100 \mu \mathrm{M})$ were measured as a function of storage time. Fig. S8 illustrates that the NPBA response of $\mathrm{H}_{2} \mathrm{O}_{2}$ and $\mathrm{CH}_{3} \mathrm{C}(\mathrm{O}) \mathrm{OOH}$ stored at room temperature decreased upto $70 \%$ and $27 \%$ after an 8 -day storage, respectivley. The decrease of the NPBA response of $\mathrm{CH}_{3} \mathrm{C}(\mathrm{O}) \mathrm{OOH}$ stored at $4{ }^{\circ} \mathrm{C}$ was similar to 15 that stored at room temperature.

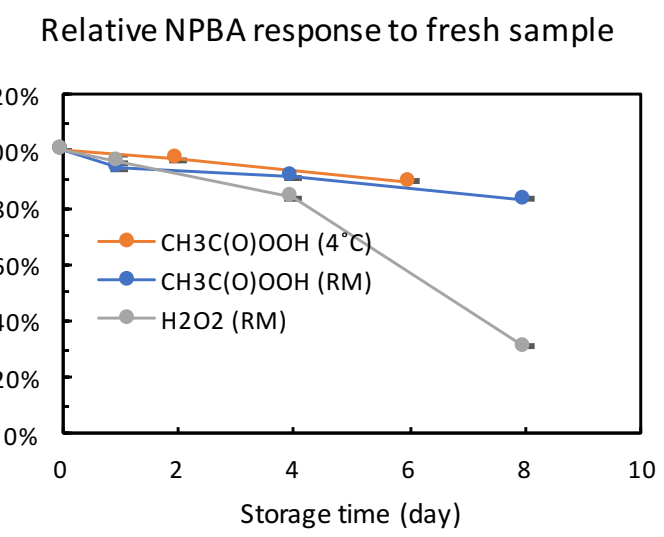

Figure S8. The NPBA responses of $\mathrm{H}_{2} \mathrm{O}_{2}$ and peracetic acid stored at room temperature or $4{ }^{\circ} \mathrm{C}$. The error bar was estimated using the standard deviation of three replicates. 


\section{S4.3. Griess assay.}

Limit of detection. LOD of Griess assay was $0.60 \mu \mathrm{M}$.

Hydrolysis time of PAN products in SOA. In this study, the hydrolysis time for PANs was set to $15 \mathrm{~min}$. To ensure that $15 \mathrm{~min}$ is enough to hydrolyse the PANs in SOA products, the Griess 5 response with 15-min hydrolysis was compared to that with 30-min hydrolysis. There was no significant difference in Griess response between a 15-min hydrolysis and a 30-min hydrolysis.

Calibration. The Griess assay was calibrated using $\mathrm{NaNO}_{2}$ solutions with varied concentrations $(1-50 \mu \mathrm{M})$, as shown in Fig. S9.

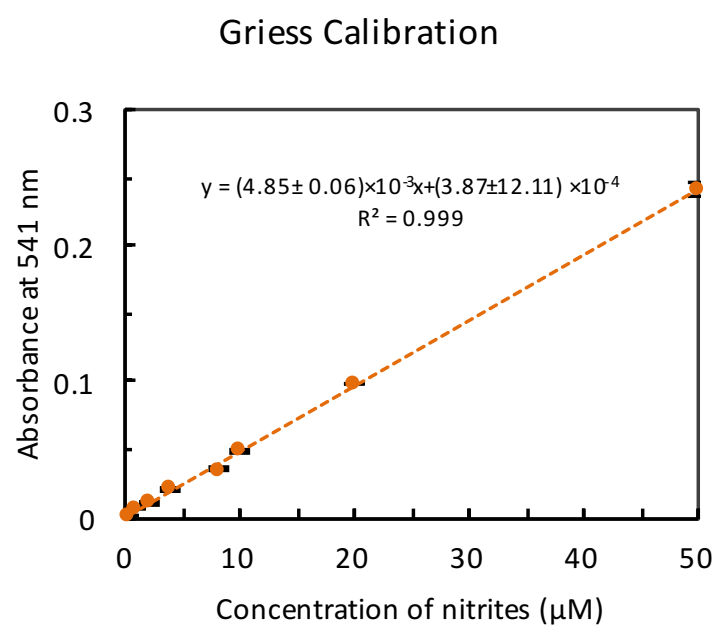

10 Figure. S9 Calibration curve of Griess assay. The error bar associated with each data point was calculated by $t_{0.90} \times \sigma / \sqrt{n}$, where $t_{0.90}$ is the t-score (2.920 for $n=3$ replicates) with a two-tail 90 $\%$ confidence level, and $\sigma$ is the standard deviation. 


\section{Section S5. Lifetime of electron-deficient alkenes under the typical chamber condition.}

Electron-deficient alkenes produced from the photooxidation of hydrocarbons can further react with oxidants, such as $\mathrm{OH}$ radicals (Finlayson-Pitts and Pitts Jr, 2000). The lifetime of two semivolatile electron-deficient alkenes (4-oxo-2-butenoic acid, and 2-hydroxy-3-penten-1,5-dial) that

5 were reported in the previous study (Jang and Kamens, 2001) was estimated using (FinlaysonPitts and Pitts Jr, 2000):

$$
\tau=\frac{1}{k[\mathrm{OH}]}
$$

where $[\mathrm{OH}]$ is the concentration of $\mathrm{OH}$ radicals, and $k$ is the rate constant (Finlayson-Pitts and Pitts Jr, 2000; Jang and Kamens, 2001). The typical concentration of $\mathrm{OH}$ radicals during the

10 photooxidation of toluene was about $2 \times 10^{-4} \mathrm{ppb}$ around noontime, estimated using the Master Chemical Mechanism (Saunders et al., 2003, 1997). The rate constants $\left(k_{4 \text {-oxo-2-butenoic acid }}(298 \mathrm{~K})\right.$ $=2.53 \times 10^{-11} \mathrm{~cm}^{3}$ molecule $\mathrm{s}^{-1}, k_{2 \text {-hydroxy-3-penten-1,5-dial }}(298 \mathrm{~K})=7.78 \times 10^{-11} \mathrm{~cm}^{3}$ molecule $\left.{ }^{-1} \mathrm{~s}^{-1}\right)$ were calculated using the structure-reactivity relationship (Kwok and Atkinson, 1995). The lifetime of 4-oxo-2-butenoic acid and 2-hydroxy-3-penten-1,5-dial was estimated to be $134 \mathrm{~min}$ 15 and 43 min, respectively. 


\section{Section S6. The concentration of gas-phase and particle-phase PAN in isoprene SOA.}

For the isoprene experiment (22 Jul. 2016), the concentrations of gas phase and particle phase PANs were measured using the Griess assay. The collection efficiency of gaseous compounds using the impinger sampling method was not determined in this study. However, the

5 concentrations of gaseous PAN products were at least 200 times higher than those of particulate PAN products, as shown in Fig. S10. The $x$-axis represents the mid-collection time (Table 1).
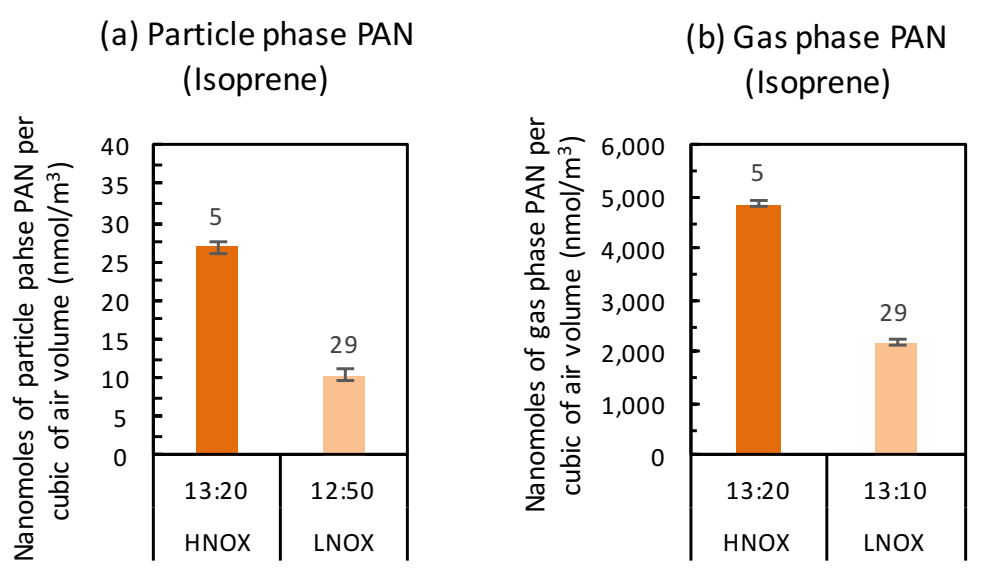

Figure S10. (a) The nanomoles of particle phase PANs (collected by a particle-into-liquid sampler) per cubic of air volume. (b) The nanomoles of gas phase PANs (collected by an

10 impinger) per cubic of air volume. The error bar of each column is the standard deviation of three replicates. The number above each column represents the initial $\mathrm{HC} / \mathrm{NO}_{x}$ ratio $(\mathrm{ppbC} / \mathrm{ppb})$. 


\section{Reference:}

Andrade, J. M. and Estévez-Pérez, M. G.: Statistical comparison of the slopes of two regression lines: A tutorial, Analytica Chimica Acta, 838, 1-12, 2014.

5 Cho, A. K., Sioutas, C., Miguel, A. H., Kumagai, Y., Schmitz, D. A., Singh, M., EigurenFernandez, A., and Froines, J. R.: Redox activity of airborne particulate matter at different sites in the Los Angeles Basin, Environ. Res., 99, 40-47, 2005.

Dou, J., Lin, P., Kuang, B.-Y., and Yu, J. Z.: Reactive oxygen species production mediated by humic-like substances in atmospheric aerosols: enhancement effects by pyridine, imidazole, and

10 their derivatives, Environ. Sci. Technol., 49, 6457-6465, 2015.

Finlayson-Pitts, B. J. and Pitts Jr, J. N.: Chapter 6 - Rates and mechanisms of gas-phase reactions in irradiated organic-NOx-air mixtures. In: Chemistry of the Upper and Lower Atmosphere, Pitts, B. J. F.-P. N. (Ed.), Academic Press, San Diego, 2000.

Giustarini, D., Rossi, R., Milzani, A., and Dalle-Donne, I.: Nitrite and nitrate measurement by

15 Griess reagent in human plasma: evaluation of interferences and standardization, Method. Enzymol., 440, 361-380, 2008.

Jang, M. and Kamens, R. M.: Characterization of secondary aerosol from the photooxidation of toluene in the presence of NOx and 1-propene, Environ. Sci. Technol., 35, 3626-3639, 2001.

Jiang, H., Jang, M., Sabo-Attwood, T., and Robinson, S. E.: Oxidative potential of secondary

20 organic aerosols produced from photooxidation of different hydrocarbons using outdoor chamber under ambient sunlight, Atmos. Environ., 131, 382-389, 2016.

Kim, Y., Hilderbrand, S. A., Weissleder, R., and Tung, C.-H.: Sugar sensing based on induced pH changes, Chem. Commun., 22, 2299-2301, 2007.

Kuivila, H. G.: Electrophilic displacement reactions. III. kinetics of the reaction between

25 hydrogen peroxide and benzeneboronic acid1, J. Am. Chem. Soc., 76, 870-874, 1954.

Kuivila, H. G. and Armour, A. G.: Electrophilic displacement reactions. IX. effects of substituents on rates of reactions between hydrogen peroxide and benzeneboronic acid1-3, J. Am. Chem. Soc., 79, 5659-5662, 1957.

Kwok, E. S. C. and Atkinson, R.: Estimation of hydroxyl radical reaction rate constants for gas-

30 phase organic compounds using a structure-reactivity relationship: An update, Atmospheric Environment, 29, 1685-1695, 1995.

Saunders, S. M., Jenkin, M. E., Derwent, R. G., and Pilling, M. J.: Protocol for the development of the Master Chemical Mechanism, MCM v3 (Part A): tropospheric degradation of nonaromatic volatile organic compounds, Atmos. Chem. Phys., 3, 161-180, 2003.

35 Saunders, S. M., Jenkin, M. E., Derwent, R. G., and Pilling, M. J.: World wide web site of a master chemical mechanism (MCM) for use in tropospheric chemistry models, Atmos. Environ., 31, 1249, 1997. 